九州大学学術情報リポジトリ

Kyushu University Institutional Repository

\title{
NEW PLATYPODIDAE (COLEOPTERA) FROM THE MOUNTAIN FORESTS OF PAPUA NEW GUINEA
}

Roberts, Hywel

Entomological Laboratory, Faculty of Agriculture, Kyushu University

Morimoto, Katsura

Entomological Laboratory, Faculty of Agriculture, Kyushu University

https://doi.org/10.5109/2500

出版情報: ESAKIA. 25，pp.161-181，1987-01-31. Entomological Laboratory，Faculty of Agriculture, Kyushu University バージョン：

権利関係 : 


\title{
NEW PLATYPODIDAE (COLEOPTERA) FROM THE MOUNTAIN FORESTS OF PAPUA NEW GUINEA*
}

\author{
HYWEL ROBERTS \\ Forest Research Station, P. 0. Box 134. \\ Bulolo, Papua New Guinea \\ and \\ Katsura Morimoto \\ Entomological Laboratory, Faculty of Agriculture, \\ Kyushu University, Fukuoka 812, Japan
}

\begin{abstract}
The very limited amount of information on the montane platypodid fauna of Papua New Guinea is summarized. As part of this fauna one new species of Baiocis and twenty-five new species of Platypus are described.

New species described are : Baiocis nubilosus, Platypus ambiguus, $P$. aspicis, $P$. bipyramidus, $P$. caelestis, $P$. capitilanatus, $P$. dobunabae, $P$. echinatus, $P$. evanidinervius, $P$. galbulimimae, $P$. glochideus, $P$. gongylodes, $P$. grumosus, $P$. ivagaii, $P$. lingulatus, $P$. margaritaceus, $P$. parapetax, $P$. partibilis, $P$. petalinus, $P$. pulvinatus, $P$. ramosissimus, $P$. ramulosus, $P$. refractus, $P$. sellaeformis, $P$. torulosus, $P$. turriformis.
\end{abstract}

\section{Introduction}

Johns (1982) defines the montane forest zone as extending from $700 \mathrm{~m}$ to $3,000 \mathrm{~m}$ in Papua New Guinea. This zone he divides into three divisions, lower- $700 \mathrm{~m}$ to $1,500 \mathrm{~m}$, mid- $1,500 \mathrm{~m}$ to $2,700 \mathrm{~m}$, and upper-montane $2,700 \mathrm{~m}$ to $3,000 \mathrm{~m}$. The new Platypodidae described in this article were taken from the two lower divisions, lower- and mid-montane. All species were collected along the Bulolo/ Watut Divide, in Morobe Province, Papua New Guinea (map reference : S $7^{\circ} 15^{\prime}$ : E 146 $36^{\prime}$ ).

The majority of Platypodidae recorded to date from the Island of New Guinea (Papua New Guinea and Irian Jaya) have been taken from lowland rain forest. Because of restricted collecting much smaller numbers have as yet been reported from mountain forest (Schedl 1970, 1972a,1972b, 1975 ; Roberts 1979, 1986). On the basis of this article, however, many more new platypodids may be expected. Besides Bulolo/Wau only Mt. Giluwe (Southern Highlands District : S 6 $2^{\circ} 2^{\prime}$ : E 1435') has had intensive collecting of Platypodidae (Roberts 1979). These mountain collections allow the

* Contribution from the Entomological Laboratory, Faculty of Agriculture, Kyushu University, Fukuoka (Ser. 3, No. 230). 
following generalities to be suggested for the montane fauna. Compared to related species from lower altitudes montane playpodids are often larger in size, and more hairy, while the colours black and yellow/orange are more common. Like the low altitude fauna some tree selection at the family level is indicated, while where related species occur in montane forests they appear also to favour the same host tree for attack. The nocturnal element of the fauna is apparently much less at high altitude, while life histories, from gallery establishment to young adult emergence, take very much longer, both these features probably reflecting lower mean annual temperatures there. In general, economically this family is not so important as pests to the timber trade in mountain forests. Logs can be left in the forest longer before they are heavily attacked by these ambrosia beetles, and the rate of wood penetration is much slower. However in standing trees attack by these insects can be common, particularly on senile trees, and in this way they are responsible for substantial timber degrade of some tree species (Roberts 1979, Gray \& Wylie 1974). Regarding the composition of this montane fauna, collecting from more widely spread localities are needed before any generalities can be made. It can be said however that there is a definite montane platypodid fauna, and certain Groups, e. $g$ 'Platypi semiopaci' (Schedl 1939) are probably found only at high altitude.

For the present study the senior author has had access to material borrowed from the Bernice P. Bishop Museum, Honolulu, Hawaii, USA, the Australian National Insect Collection, Canberra, Australia, the British Museum (Natural History), London, and the Naturhistorisches Museum, Vienna, Austria.

The following abbreviations are used for depositories containing specimens :

BMNH -British Museum (Natural History), London ;

FRS, Bulolo -Forest Resaearch Station, Bulolo, Papua New Guinea

Baiocis nubilosus sp. nov. (Fig. 29)

Male 2.7 to $\mathbf{2 . 8} \mathrm{mm}$ long, and five times as long as wide. Colour orange/brown, the base of the elytra paler. Head anteriorly flat, posteriorly inclined, median stria prominent, surface with numerous clear, piliferous punctures; vertex strongly angled to frons, the junction marked by a distinct transverse ridge. Pronotum plainly longer than wide $(27: 17)$, femoral grooves narrow, not strongly angled, median stria very evident, at its anterior limit impressed, surface shining, with scattered fine punctures. Elytra the same width as the pronotum and nearly twice as long, parallel sided, before narrowing in the last quarter to a transverse, narrowly lunate declivity; disc shining, interstriae and striae not distinct, the latter seriate punctate; declivity with serrate margins which narrow to a transverse rim, below the margins apico-laterally one distinct short tooth on each side, hardly visible in dorsal view, the transverse rim lightly carinate above, and well coverd with short hairs, after which reflected below onto a smooth, shining, centre piece. Abdominal ventrites obliquely raised, except the last granular, with numerous hairs.

Female $2.9 \mathrm{~mm}$ long, and a little over five times as long as wide. Colour darker than the male. Head and Pronotum very like the male. Elytra again similar to the male except near the declivity not narrowing as much, less transverse at apex, and without serrate margins, or the single tooth on the underside, surface densely haired.

Holotype $\Im^{7}$, Papua New Guinea :Gumi, Watut Logging Area, Bulolo, 2,200 m, ex Garcinia sp., 11. xii. 85 (H. Roberts) (BMNH). Paratypes $10^{7} 2 \%, 1 q$ (BMNH), $1 \sigma^{\top} 1 q$ (FRS, Bulolo).

This species is close to B. unispineus Roberts (Fig. 30) and B. imitatrix Schedl and B.annularis Schedl. The male of $B$. nubilosus is distinguished from both by its larger size, and by the small size of the apico-lateral tooth of each elytron, which causes the angles of the elytra to project only a little behind the level of the sutural limit, unlike the two other species. 


\section{Platypus ambiguus sp. nov. (Fig. 27)}

Male 4.2 to $4.3 \mathrm{~mm}$ long, and four times as long as wide. Colour uniform dark brown. Head frons lightly impressed, median stria short, surface matt, finely ruminate ; vertex angled to frons, median stria prominent. Pronotum a little longer than wide (34:31), femoral grooves angled posteriorly, median stria distinct, surrounded by two comparatively large pore-groups, the pores widely spaced, surface shining, with many fine irregular punctures. Elytra nearly twice as long as pronotum, with sides diverging to convex apical declivity, widest at summit of declivity, which occupies almost all distal half ; disc shining basally, distally matt, interstriae conspicuous only in basal half, 1 very narrow, the remainder wider and subequal, 3 and 8 alone prominent in distal half of elytra, each straight, and ending in a point, striae seriate punctate, other than first not impressed ; declivity convex, no clear indication of interstriae or striae, matt all over, with numerous granules, one pair near the elytral apex larger than all others, lightly covered all over with irregular rows of hairs. Abdominal ventrites matt, granular, with numerous hairs.

Female 4.6 to $4.7 \mathrm{~mm}$ long, and more than four times as long as wide, near parallel sided. Head and Pronotum similar to male except frons with a pair of frontal lamellae, one on either side of the median stria, the distance between them being at least half the length of the lamellae, while the pronotum has much larger pore-groups, which in outline are elongate to oval. Elytra more than twice as long as pronotum, with declivity occupying only distal sixth ; disc shining, interstriae and striae not distinct, though clearly showing on commencement of declivity ; at first declivity inclined then vertical, impressed along the suture, surface basally finely carinate with few hairs, distally, where it is vertical, a dense covering of short hairs, except along the sutural strip.

Holotype $\sigma^{\gamma}$, Papua New Guinea :Gumi, Watut Logging Area, Bulolo, 2,200 m, ex Planchonella sp., 13. ii. 86 (H. Roberts) (BMNH). Paratypes $10^{\top} 2 \%$, same data as holotype, 19 (BMNH), $1 \sigma^{\top} 1 \%$ (FRS, Bulolo).

This species belongs to the Group 'Platypi semiopaci'. The males of this Group, of which there are many species, are best separated on the form of the pronotal pore-group and the shape of individual elytral interstria, and females by the length and location of the frontal lamellae. Descriptions of already known species have too often lacked these details, and the texts do not allow easy separation of the species. P. ambiguus is close to P.uniformis Schedl (Fig. 28) and P. denticollis Browne. Males of the new species are distinguished by the large pronotal pore-groups, in which individual pores are widely spaced, and by the prominence and shape of elytral interstriae 3 and 8 , and females by the location of the frontal lamellae, which are much farther apart than in P. uniformis. Regarding this Group the reference in Roberts (1979), in both text and Fig. 2, to P.uniformis Schedl should be to $P$. semiopacus Strohmeyer.

\section{Platypus aspicis sp. nov. (Fig. 34)}

Male 4.7 to $4.8 \mathrm{~mm}$ long, and more than three times as long as wide. Colour head and thorax orange, elytra red to black. Head frons near flat, median stria well developed, with scattered piliferous punctures in upper half, fine structure reticulate, matt; vertex strongly angled to frons, no median enclosure. Pronotum almost square, median stria impressed and surrounded anteriorly by two pore-groups, the pores reduced to fine, short lines, surface shining with piliferous punctures, particularly near anterior margin. Elytra twice as long as pronotum, with abrupt declivity, and barbed lateral margins ; interstriae 3 and 8 prominent, the latter contributing to the margin of the declivity, the remainder all very narrow and incomplete, but all reaching the upper margin of the declivity where only 1, 3 and 5 clearly project over it, striae wider than most interstriae, and each with a line 
of granules ; declivity abrupt, without any clear indications of interstriae or striae, margin finely raised, on each elytron below interstriae 3 a prominent granule, otherwise only a few small granules near the margin, surface matt. Abdominal ventrites shining, lightly granulose.

Female 5.1 to $5.2 \mathrm{~mm}$ long. Colour red-brown. Head and Pronotum like male except median stria on frons larger and impressed, and pronotal pore-groups much bigger, occupying complete length of median stria. Elytra simpler than male, with declivity limited to less than last quarter, the terminal
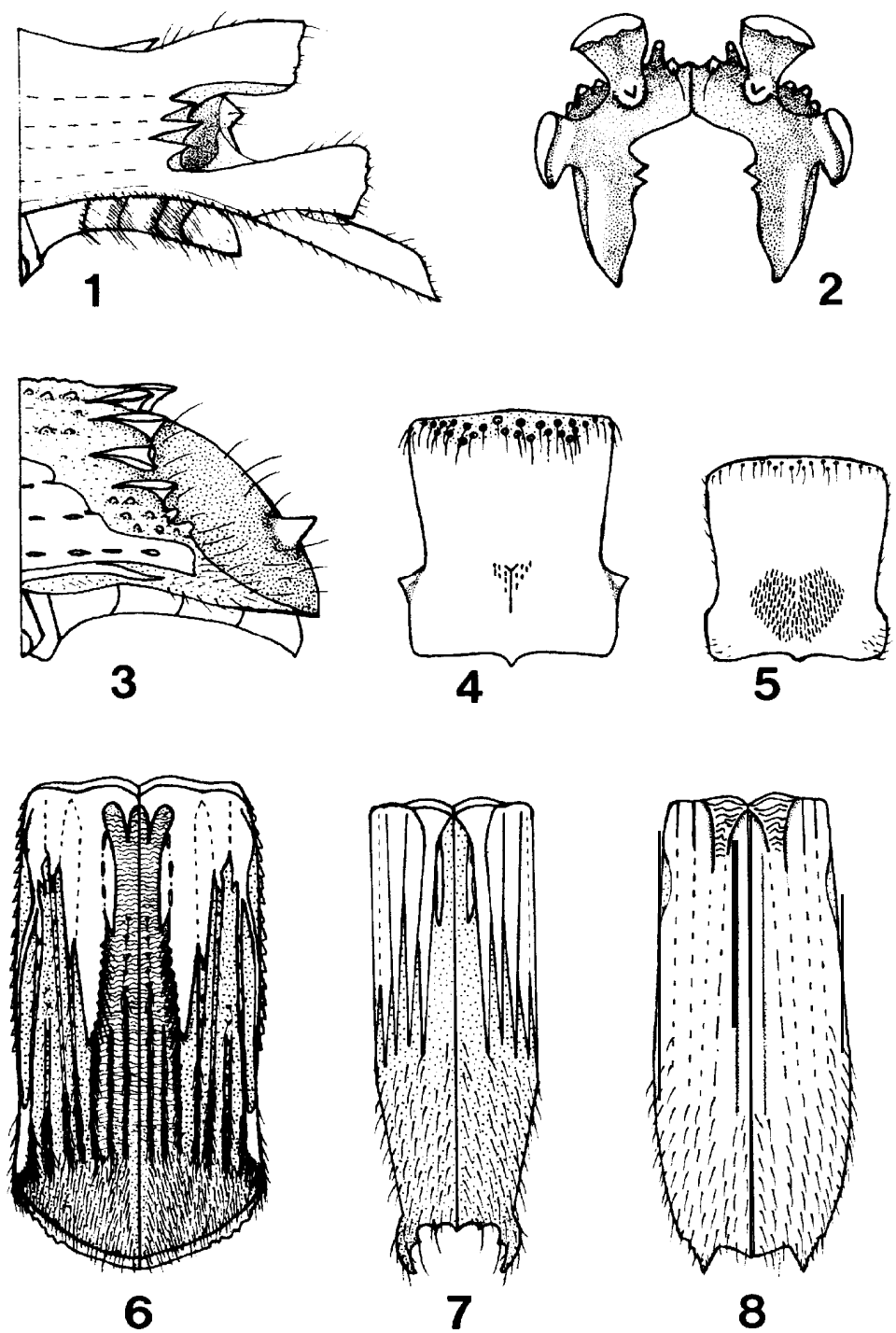

Figs. 1-8. Platypus ramulosus sp. nov : 1. lateral view apex male elytron ; 2 . posterior view male declivity. $P$. dobunabae sp. nov. : 3. lateral view apex male elytron. P. ivagaii sp. nov. : 4. dorsal view male pronotum ; 6 . dorsal view male elytra. $P$. caelestis sp. nov : 5 . dorsal view male pronotum ; 7 . dorsal view male elytra ; 8 . dorsal view female elytra. 
part vertical ; interstriae and striae much less prominent than male, the latter clearly punctured, though little impressed; declivity distinguished by the vertical apex being bordered above by oblique ridges, and covered by a dense mass of short hairs.

Holotype ơ. Papua New Guinea : Gumi, Watut Logging Area, Bulolo, 2,200 m, ex sticky trap on Galbulimima sp., 26. xi. 85 (H. Roberts) (BMNH). Paratypes $10^{\top} 2 q$, same data as holotype, 19 (BMNH), $10^{\top} 1$ (FRS, Bulolo).

This species closely resembles P.obliquecaudatus Schedl in the Group 'Platypi sulcato-truncati' (Schedl 1972a). Males of P.aspicis are distinguished by the individual pronotal pores being fine lines, not round, by the interstriae not all projecting over the declivity strongly, and finally by the simpler ornamentation of declivity with only one pair of distinctive granules.

\section{Platypus bipyramidus sp. nov (Fig. 23)}

Male 3.1 to $3.2 \mathrm{~mm}$ long, and nearly four times as long as wide. Colour yellow-brown, with elytral apices black. Head frons flat, lightly impressed between the eyes, median stria short, surface matt, finely ruminate, with few short hairs; vertex angled with frons. Pronotum near square, median stria short with distinct group of 6 to 9 pores on either side of anterior limit, surface smooth, shining, with very few punctures. Elytra slightly more than twice as long as pronotum (60:28), parallel sided for basal two thirds, then rapidly narrowing to a blunt apex ; disc shining, interstriae not all distinct, 9 with a row of barbs visible from above, striae punctate but not impressed ; declivity occupying posterior third, initially gradually convex, then sharply so, interstriae as fine, raised ridges, strongly evident to begin with, each except 1,8 and 9 divided in two, all then continuing on the steep part of declivity as rows of small granules, those terminating row 3 much larger, all granules with one to three yellow hairs, general surface matt. Abdominal ventrites matt, with scattered granules and few hairs.

Female 3.8 to $3.9 \mathrm{~mm}$ long. Colour orange except for black head and elytral apices. Head and Pronotum like the male except pronotal median stria surrounded by two pore-groups, cordate shaped. Elytra simpler than the male, twice as long as the pronotum, sides near parallel, ending in declivity at first convex, then transverse and vertical, occupying final fifth ; disc shining, interstriae not very distinct throughout, striae likewise, except first and eighth which are impressed ; declivity no inter striae or striae evident, where convex lightly carinate, with few hairs, suture impressed, this area separated from vertical part by vague oblique ridges that end on posterior margin in two small notches, surface granulose with horizontal hairs, suture here raised.

Holotype ơ', Papua New Guinea : Gumi, Watut Logging Area, Bulolo, 2,200 m, ex Xanthomyrtus sp., 18. ix. 86 (H. Roberts) (BMNH). Paratypes 10 29, same data as holotype, 19 (BMNH), lb 1q(FRS, Bulolo).

This species belongs to the Group 'Platypi antennati' (Chapuis 1865), being close to P. striatodeclivis Schedl and $P$. echinatus sp. nov. Males of $P$. bipyramidus are separated from both these species by the absence of any spines at the base of the declivity, as well as being smaller in size.

\section{Platypus caelestis sp. nov. (Figs. 5, 7, 8)}

Male 3.0 to $3.1 \mathrm{~mm}$ long, and 3.5 times as long as wide. Head and elytra brown to black, pronotum yellow. Head frons near flat, no central stria, surface matt, with many small irregular elongate punctures and long scattered hairs; vertex not strongly angled to frons. Pronotum longer than wide $(30: 27)$, femoral grooves very shallow, pore-group conspicuous, cordiform, the individual pores elongate, surface shining with scattered minute punctures. Elytra of similar width to pronotum, but more than twice as long, for basal two thirds near parallel sided, then narrowing to two apical 
projections ; all interstriae on disc shining, 1 and 2 short and narrow, the remainder longer, only the first 5 interstriae completely, or partly distinct ; declivity shallowly inclined, matt throughout, laterally extended as prominent projection on each elytron, apices carinate, and marked by rows of short hairs. Abdominal ventrites matt all over, with scattered hairs.

Female 2.9 to $3.0 \mathrm{~mm}$ long. Of similar form and colour to the male, but lacks the two strong projections terminating the elytra. Head and Pronotum as male except median stria on frons more pronounced, and pronotal pore-group larger. Elytra disc shining throughout, except for 1 all interstriae similar, striae seriate punctate, not impressed ; declivity restricted to apical fifth, no trace of interstriae or striae, at first gradually convex, then near vertical, margins notched on each side, surface matt, transversely carinate, with numerous short hairs on the vertical part.

Holotype ${ }^{7}$, Papua New Guinea : Gumi, Watut Logging Area, Bulolo, 2,200 m, ex Macaranga sp., 23. i. 86 (H. Roberts) (BMNH). Paratypes $10^{\top} 2 q$ same data as holotype, $19(\mathrm{BMNH}), 10^{\top} 19$ (FRS, Bulolo).

Belonging to the Group 'Platypi oxyuri' (Chapuis 1865) this species resembles P. giluwei Roberts. Males of P.caelestis can be distinguished by the more elongate declivity, of which the surface is all matt, and both sexes can be recognized by the very elongate pores of the pronotal pore-group.

\section{Platypus capitilanatus sp. nov. (Figs. 14, 15)}

Male : 3.6 to $3.7 \mathrm{~m}$ long, and four times as long as wide. Colour uniform chocolate brown. Head near flat, frons with shallow median stria, surface granulous; vertex clearly angled to frons. Pronotum a little longer than wide $(25: 21)$, femoral grooves strongly angled only behind, posteriorly a very fine short median stria surrounded by an irregular cordate group of pores, surface near smooth, shining. Elytra not wider than pronotum, and nearly three times as long, somewhat bulbous, and ending in a pair of strong lateral projections, with between a much smaller pair, declivity very narrow, near vertical ; disc shining, interstriae 1 raised, narrow, remainder wider, subequal, all losing their identity before the declivity, striae except the first not impressed, lightly punctate ; declivity very narrow, marked on each elytron at the limit of interstriae 3 by a short notched projection, and at the limit of interstriae 7 by a very prominent spine. Abdominal ventrites smooth, shining, with scattered rows of yellow hairs.

Female 3.7 to $3.8 \mathrm{~mm}$ long, and nearly four times as long as wide. In form generally similar to the male, but distinguished by the Head which between and below the eyes bears a marginal strip of long incurving yellow hairs, and the Elytra which are without any prominent posterior projections. Length, proportions and colour near the male. Pronotum like the male except the pore-group larger, and the median stria better defined. Elytra similar to the male over the disc, but the declivity more extensive, occupying the last quarter of the elytra, at first convex, then vertical, the projections being reduced to very short, blunt teeth, the surface lightly granular all over, with a good covering of short hairs.

Holotype ơ , Papua New Guinea : Gumi, Watut Logging Area, Bulolo, 2,200 m, ex Dysoxylum sp., 12. ii. 86 (H. Roberts) (BMNH). Paratypes $20^{7} 39,1 \%(\mathrm{BMNH})$ same data as holotype, $10^{7} 1$ \% Kaisenik Logging Area, Wau, 2,000 m, ex Ficus sp., 15. v. 77 (H. Roberts) (FRS, Bulolo), and 10 19 Manki Logging Area, Bulolo, 1,850 m, ex Prunus sp., 10. vii. 85 (H. Roberts) (FRS, Bulolo).

This interesting species resembles closely P.chimbui Schedl, of which only the male is known (Schedl 1972). Males of P. capitilanatus are separated by the form of the projections terminating the elytra. Females with conspicuous frontal hairs are only known to the authors within the Group 'Platypi paraspinulosi' (Schedl 1972), known from rain forest in Central and West Africa. 


\section{Platypus dobunabae sp. nov. (Fig. 3)}

Male 4.6 to $4.7 \mathrm{~mm}$ long, nearly three times as long as wide. Colour deep red-black, declivity darker. Head near flat, with a very short, but distinct, median sulcus on the frons, surface granulous, particularly between the antennae; junction of frons and vertex rounded, the latter with a distinct median striae. Pronotum slightly longer than wide (39:36), femoral grooves shallow, angled only behind, median sulcus short and impressed, with very few fine pores at its anterior limit, surface shining with numerous scattered strong pits, particularly in posterior half. Elytra a little wider than the pronotum, and just less than three times as long, sides near parallel for three quarters of their length before ending in a rounded apex, declivity confined to apical quarter; disc shining distally, apically matt, granular, interstriae smooth, not raised, the first very narrow, and ending well before the declivity, the remainder much wider, subequal and progressively longer, striae finely seriate punctate, nowhere impressed ; declivity convex, marked at its upper limit by a ring of near even sized large granules, with two prominent pointed bosses, one on each elytron, surface finely matt throughout, with scattered curved hairs. Abdominal ventrites matt, with numerous prominent hairs.

Female 5.4 to $5.5 \mathrm{~mm}$ long, more than tree times as long as wide. Colour red-black. Head near flat, distinguished by a pair of elongate frontal lamellae, with between them an impressed medium striae, surface coarsely granulous. Pronotum nearly square (26:25) with large cordiform pore-group separated by a prominent striae, surface more lightly punctured than the male. Elytra a little wider than the pronotum and more than twice as long, ending in convex declivity ; disc shining, all interstriae and striae ending before commencement of near vertical declivity, interstriae 1 very narrow, remainder much wider, all subequal, only the first striae impressed, declivity as with other members of this Group with oblique ridge on each elytron, the area in between covered with conspicuous, obliquely inclined yellow hairs.

Holotype $\sigma^{\top}$, Papua New Guinea :Gumi, Watut Logging Area, Buloko, 2,200 m, ex Galbulimima belgraveana, 23. i. 86 (H. Roberts) (BMNH). Paratypes $20^{7} 39$, same data as holotype, $10^{\top} 2$ ( $\mathrm{BMNH}$ ), 1071 (FRS, Bulolo).

This new species belongs to the 'Platypi semiopaci'. Males can be distinguished from all others by the ring of prominent granules surrounding the declivity, and females by the elongate frontal lamellae.

This platypodid is named after colleague of the senior author, Mr. J. Dobunaba, who has done the illustrations for this and other taxonomic articles.

\section{Platypus echinatus sp. nov. (Fig. 33)}

Male 3.8 to $3.9 \mathrm{~mm}$ long, and more than three times as long as wide. Colour reddish brown. Head frons centrally impressed, with short median stria, surface irregularly rugose all over, dull with marginal hairs ; vertex clearly angled to frons, with well developed median stria. Pronotum only a little longer than wide $(34: 32)$, femoral grooves very shallow, median stria with no pore-groups, surface shining, with scattered small punctures. Elytra not twice as long as pronotum, blunt, the declivity occupying more than one third of the elytral length, bearing spines, some prominent ; disc shining, strongly grooved, interstriae 1 narrow, all the remainder wider and bifurcate, 2 and 3 fused and smooth for nearly half the elytra, between the rami of these interstriae 2, 4, 6, and 8 with prominent hooked spines at the top of the declivity, on 9, visible from above, a row of small spines, striae impressed, because interstriae bifurcate apparently more than usual, seriate punctate only basally ; declivity convex, ridges of interstriae all carried down onto upper half, after which only a few scattered granules, posterior margin with two pairs of separate, distinct larger granules, surface 
matt, with rows of hairs representing elytral striae. Abdominal ventrites matt, granulose, with hairs.

Holotype ơ', Papua New Guinea :Gumi, Watut Logging Area, Bulolo, 2,200 m, ex Cryptocaria sp., 4. v. 76 (H. Roberts) (BMNH).

This distinctive male is closely related to P.striatodeclivis Schedl and P.bipyramidus sp. nov. Besides being larger P.echinatus is clearly separated by the presence of four pairs of prominent
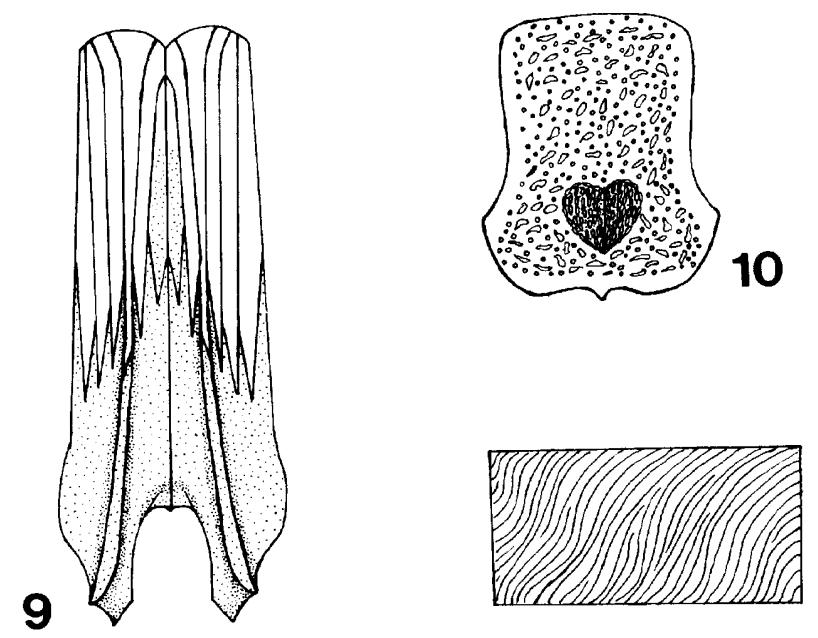

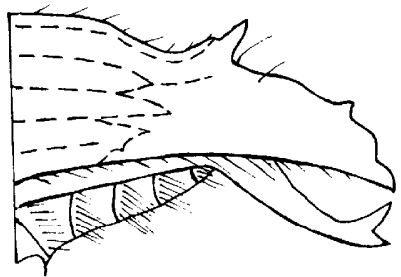

12

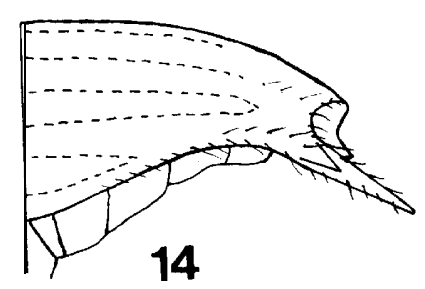

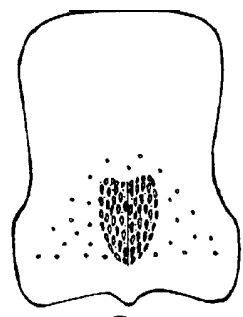

13

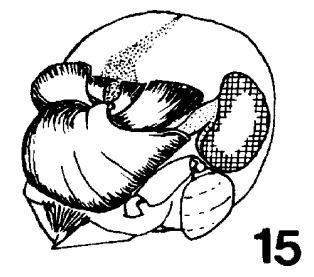

Figs. 9 - 15. Platypus sellaeformis sp. nov. : 9. dorsal view male elytra ; 10. dorsal view female pronotum ; 11. fine structure pronotum surface. P.ramosissimus sp. nov. : 12. lateral view female elytron ; 13. dorsal view female pronotum. P. capitilanatus sp. nov. : 14. lateral view male elytron ; 15. oblique view head of female. 
hooked spines near the top of the declivity, which are much better developed than similar teeth on $P$. striatodeclivis.

\section{Platypus evanidinervius sp. nov. (Fig. 32)}

M ale 4.0 to $4.1 \mathrm{~mm}$ long, and three times as long as wide. Colour black. Head frons near flat, with distinct, short, median stria, surface with many elongate piliferous punctures, fine structure reticulate ; vertex angled to frons, with prominent circular central impression occupying nearly half the width of the vertex. Pronotum a little longer than wide (29:27), median stria distinct with no poregroups, surface shining, with scattered small punctures. Elytra hardly wider than the pronotum, but twice as long, ending in near vertical declivity which occupies the final quarter ; disc shining, all the interstriae evident throughout, but none clearly reaching the top of the declivity, interstriae 3 and 8 the most prominent, striae all impressed throughout and getting wider towards declivity, surface matt, each with a row of fine granules ; declivity at first convex, then vertical, none of the interstriae or striae clearly evident, though the termination of each interstriae marked by a bush of hairs, on each elytron opposite interstriae 3 a prominent pointed boss, surface matt, covered with small granules and numerous hairs. Abdominal ventrites granular, with many hairs.

Female 4.8 to $4.9 \mathrm{~mm}$ long, and nearly four times as long as wide. Colour black. Head and Pronotum very similar to male. Elytra a little wider than pronotum, and nearly twice as long, surface shining, all interstriae and striae distinct up to commencement of declivity, though none prominent, striae irregularly punctate ; declivity first convex, then vertical, with centre of the latter part concave, elytral suture impressed at first, distinctive oblique ridges separating the change in slope on both elytra, hairs long, and pointing backwards up to, and particularly on the oblique ridges, after these much shorter, and pointing outwards from a bare sutural margin.

Holotype $\sigma^{\top}$, Papua New Guinea : Upper Stony Logging Area, Bulolo, 1,600 m, ex Syzigium sp., 9. v. 86 (H. Ivagai) (BMNH). Paratypes $10^{\top} 2 \%$, same data as holotype, 19 (BMNH), $10^{\top} 19$ (FRS, Bulolo).

The male P. evanidinervius is separated from other 'Platypi sulcato-truncati' by the clarity of both interstriae and striae throughout the elytral disc. Females, in the authors opinion, are unique in this Group in having no pronotal pore-groups ; the ornamentation of the declivity is also distinctive.

\section{Platypus galbulimimae sp. nov.}

M ale 3.6 to $3.7 \mathrm{~mm}$ long, and nearly four times as long as wide. Colour near black. Head frons lightly impressed between the eyes, the short median stria clearly visible, surface with many shallow piliferous punctures, fine surface reticulate; vertex angled to frons, surface similar. Pronotum only a little longer than wide (15:14), median stria distinct, no evident pore-group, surface covered somewhat densely with variably sized, shallow punctures. Elytra a little wider than the pronotum, and twice as long, the ribbed shining disc ending in a strongly inclined declivity ; interstriae 3 and 5 prominent for most of disc, these two, together with 1 and 6 , alone are evident separately at top of the declivity, while 7 to 9 are fused, all these interstriae ending in horizontal tufts of yellow-gold hairs, striae broad, very finely reticulate all over ; declivity obliquely truncate, interstriae 1, 3, 5 and 6 continuing onto declivity as raised ribs, 1 the largest, though only 1 and 5 clearly reaching the declivity apex, the latter distinguished by three notches, the second being much larger than the other two, surface generally matt, with rows of hairs on the raised ridges. Abdominal ventrites matt, punctate.

Female 3.9 to $4.0 \mathrm{~mm}$ long, and almost four times as long as wide. Colour black. Head and 
Pronotum like male except stria of both more conspicuous, and a single irregular line of pores on both sides of pronotal stria, which could be simple pore-groups. Elytra a little wider than the pronotum, and twice as long, declivity much simpler than the male; all interstriae and striae distinct up to commencement of declivity, though neither prominent, surface dull ; declivity at first gradually convex then near vertical, with one conspicuous notch on either side where an oblique ridge terminates, apices bluntly pointed, surface granular near centre.

Holotype ơ , Papua New Guinea :Gumi, Watut Logging Area, Bulolo, 2,200 m, ex Galbulimima sp., 5. vii. 85 (H. Roberts) (BMNH). Paratype 1029, same data as holotype, 10 (BMNH), 10 1 1 (FRS, Bulolo).

This species is closely related to the smaller P. nudiusculus Roberts and P. daedalus Roberts. Males of $P$. galbulimimae are distinguished besides size by the more prominent stria of both frons and pronotum, and by the stronger sutural teeth terminating the declivity. In what appears to be the preferred host tree, Galbulimima, this new species was common, and its galleries can always be distinguished on the tree surface by a projecting cylinder of wax.

\section{Platypus glochideus sp. nov. (Fig. 35)}

Male 3.2 to $3.3 \mathrm{~mm}$ long, and four and a half times as long as wide. Colour yellow, with elytral apices black. Head frons near flat with a conspicuous median stria, surface matt, with piliferous punctures ; vertex strongly angled to frons, with prominent V-impression centrally. Pronotum clearly longer than wide $(25: 18)$, median stria very distinct, surrounded for more than anterior half by poregroups, surface shining, few punctures. Elytra twice as long as pronotum, lateral margins barbed, ending in strongly angled declivity, that occupies less than the last quarter ; interstriae 3 prominent on disc, wider than remainder, all of which are matt, 5, 7, and 9 are barbed, all interstriae reach declivity margin, 8 and 9 contributing to its prominent keel, striae all impressed, impunctate; declivity strongly keeled posteriorly, interstriae 1 to 6 appearing briefly at apex, surface granular all over, with numerous hairs. Abdominal ventrites punctured, piliferous, shining.

Female 3.3 to $3.4 \mathrm{~mm}$ long. Colour like the male, and of similar proportions. Differs from the male in the more conspicuous stria on the frons, the larger number of pores in the pronotal poregroups, and in the simpler declivity terminating the elytra, which is slightly impressed apically and has the vertical surface thickly covered with long hairs.

Holotype ơ, Papua New Guinea : Gumi, Watut Logging Area, Bulolo, 2,200 m, ex Planchonella sp., 28. vi. 76 (H. Roberts) (BMNH). Paratypes 16 29, same data as holotype, 19 (BMNH), $10^{\top} 1$ ( $(\mathrm{FRS}$, Bulolo).

This species resembles P.truncaticauda Schedl in the Group 'Platypi truncatipenni' (Schedl 1972). $P$. glocha'deus is distinguished by its slimmer form. Males are distinctive in having pronotal poregroups, by the conspicuousness of interstriae 3 on the elytra, and by the absence of the peg-like projections that terminate the declivity of $P$. truncaticauda.

\section{Platypus gongylodes sp. nov. (Fig. 22)}

Male 2.8 to $2.9 \mathrm{~mm}$ long, and four times as long as wide. Colour reddish brown, the elytral apices black. Head frons lightly impressed with a clear short stria, surface finely reticulate, with few hairs ; vertex not strongly angled to frons. Pronotum clearly longer than wide $(30: 25)$, femoral grooves shallow, posterior median stria with only two or three distinctive pores near its anterior limit, surface shining, with few scattered punctures. Elytra not wider than the pronotum, but more than twice as long, disc shining, followed by matt elongate declivity occupying some two fifths of the elytra, and 
ending in a short vertical face, with one pair of very short projections; interstriae 1 and 9 very narrow, remainder wider and subequal, part glabrous, part matt, the length of the shiny portions increasing from the suture, from 1 to 6 , striae seriate punctate, only the first and second strongly impressed ; both interstriae and striae continued onto declivity basally, the latter terminating in a pair of small inclined, indented plates, one on each elytron, surface matt throughout, the interstriae marked with lines of spaced granules, those terminating the interstriae somewhat larger, short backwardly pointing hairs alternating with these granules. Abdominal ventrites shining, with many prominent hairs.

Holotype ơ? Papua New Guinea : Gumi, Watut Logging Area, Bulolo, 2,200 m, ex Syzigium sp., 20. i. 86 (H. Roberts) (BMNH). Paratypes $20^{\circ}$, same data as holotype, $10^{\top}$ (BMNH), $10^{\top}$ (FRS, Bulolo).

This species appears best placed in the 'Platypi antennati', though a somewhat aberrant example. Its slim elongated shape, terminating in two small elytral projections distinguish the males from all other species in the Group.

Platypus grumosus sp. nov. (Figs. 16, 17, 18)

Male 3.9 to $4.0 \mathrm{~mm}$ long, and three times as long as wide. Colour chocolate brown. Head frons flat, with distinct median stria, surface finely reticulate with piliferous punctures, best developed in the upper half ; vertex angled to frons, with well developed inverted V-impression, which is margined with strong hairs. Pronotum nearly square, distinct posterior median stria, with a pair of pore-groups at its anterior limit, surface shining, with scattered punctures. Elytra more than twice as long as pronotum, but only a little wider, declivity occupying posterior third, and strongly angled to disc ; interstriae all reaching upper margin of declivity, 1, 5, and 9 throughout nearly separate, while 2 to 4, and 6 to 8 joined for half of elytra, among striae third and fourth alone clearly punctate, and only for basal half, remainder impunctate, and largely impressed ; declivity with marginal rim, interstriae and striae recognizable only near upper margin, the interstriae all strongly haired, interstriae 3 terminated by a prominent boss, surface matt, with many flattened granules. Abdominal ventrites shining, piliferous.

Female 4.0-4.1 mm long, and of similar colour. Head and Pronotum like the male except frontal stria longer, and pronotal pore-groups better developed. Elytra two and a half times as long as pronotum, with a simple declivity, the apex vertical ; disc shining, with only interstriae 1 and the first stria distinct throughout, declivity with many short yellow hairs on the vertical part.

Holotype $\sigma^{\Im}$, Papua New Guinea :Gumi, Watut Logging Area, Bulolo, 2,200 m, ex Agathis alba, 13. iv. 76 (H. Roberts) (BMNH). Paratypes 20'19, same data as holotype, 19 (BMNH), 26 (FRS, Bulolo).

This species belongs to the Group 'Platypi sulcato-truncati' and resembles P. nothofagus Roberts. Males of $P$. grumosus are separated by their larger size, by the smaller pore-group of the pronotum, by the basally joined elytral interstriae, and by the ornamentation of the declivity.

\section{Platypus ivagaii sp. nov. (Figs. 4, 6)}

Male 4.9 to $5.0 \mathrm{~mm}$ long, and three and half times as long as wide. Colour head and thorax yellow, the elytra reddish-brown. Head frons flat, with a short median stria at the lower limit of the eyes, surface matt all over with short hairs; vertex angled to the frons, with centrally an inverted parabola -shaped groove which carries a row of hairs, surface within the groove shining, outside it matt. Pronotum almost square, femoral grooves posteriorly angled, a short impressed posterior median stria that is anteriorly divided, and on either side of this a small number of indistinct pores, surface near 
smooth, shining. Elytra a little wider than pronotum and twice as long, sides straight, slightly diverging until reaching the steeply inclined declivity ; disc shining, interstriae generally reduced to rows of piliferous granules except for bases of 3 and 4 which are very wide, while 2, 5, 6, 7, and 8 are likewise but narrow, only 8 reaches the top of the declivity, where with 7 it contributes to the rim, striae impunctate, surface reticulate throughout ; declivity conspicuously rimmed, with no evidence
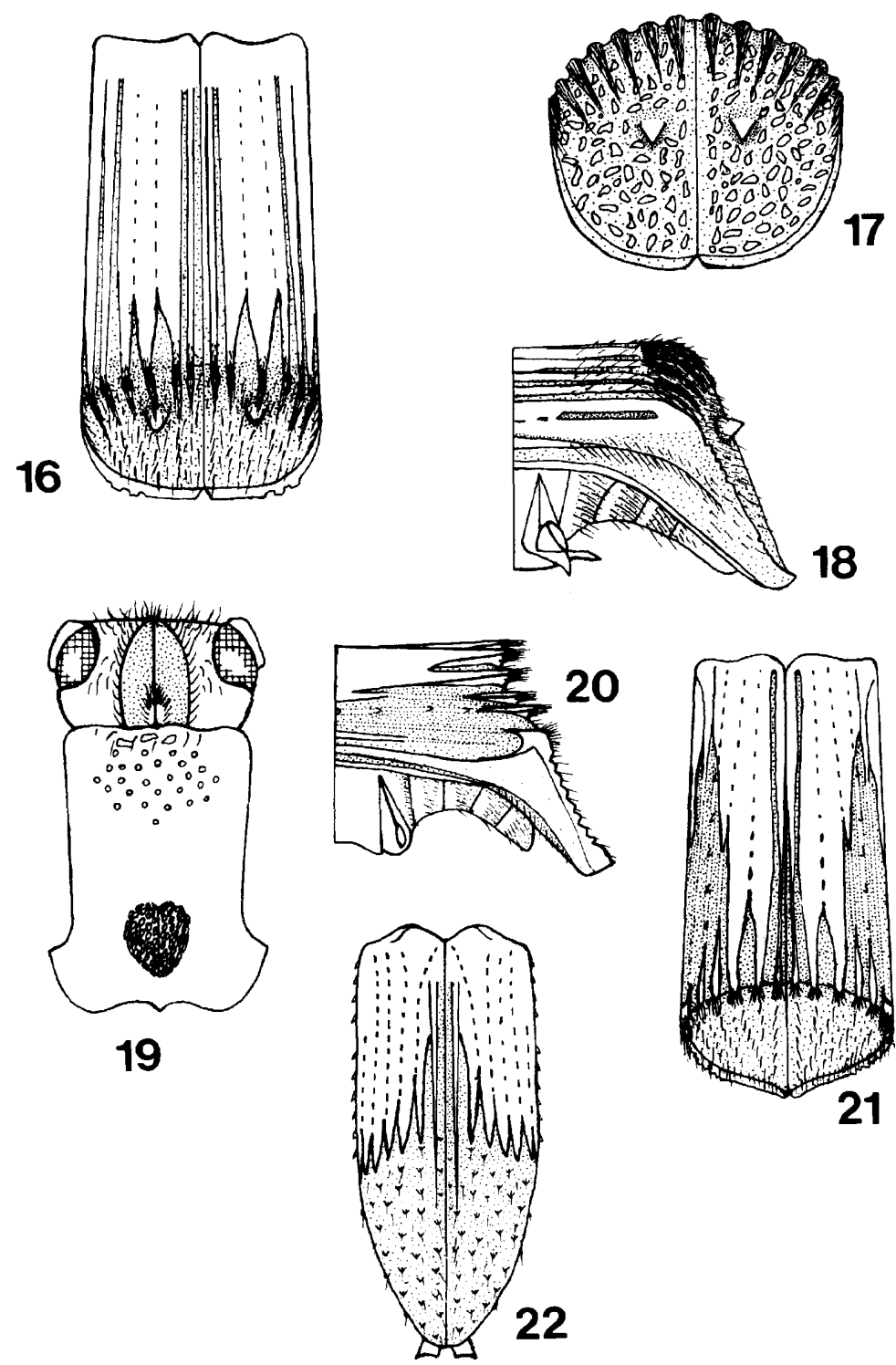

Figs. 16 -22. Platypus grumosus sp. nov. : 16. dorsal view male elytra ; 17. posterior view male declivity ; 18. lateral view apex male elytron. P.turriformis sp. nov. : 19. dorsal view head and pronotum female ; 20 . lateral view apex male elytron ; 21. dorsal view male elytra. $P$. gongylodes sp. nov. : 22. dorsal view male elytra. 
of any interstriae, surface matt, covered with scattered piliferous granules, that get smaller in size toward the elytral apices. Abdominal ventrites shining, with few hairs.

Female 4.9 to $5.0 \mathrm{~mm}$ long, and more than four times as long as wide. Colour similar to the male. Head and Pronotum like the male except the pronotal pore-group much larger, and cordiform in outline. Elytra quite different to the male, with the disc traversed by distinct interstriae and striae throughout, and the declivity being simple, at first convex, then vertical, the latter part covered with a dense brush of yellow hairs, each on a small granule.

Holotype $\sigma^{\circ}$, Papua New Guinea :Gumi, Watut Logging Area, Bulolo, 2,200 m, ex Garcinia sp., 5. vii. 85 (H. Ivagai) (BMNH). Paratypes $10^{\Uparrow 1} 1$, same data as holotype, $19(\mathrm{BMNH})$ and $10^{7}$ (FRS, Bulolo).

This conspicuous platypodid belongs to the 'Platypi sulcato-truncati' where it resembles $P$. truncatigranosus Schedl. Compared to the latter males of $P$. ivagaii are distinguished by their much larger size, and by the very prominent interstriae 3 on the elytra.

This insect is named after Mr. H. Ivagai who as a colleague has contributed very much in collecting biological data on Platypodidae in Papua New Guinea.

Platypus lingulatus sp. nov. (Fig. 36)

Male 3.1 to $3.2 \mathrm{~mm}$ long, and three and a half times as long as wide. Colour yellow with apices of abdomen black. Head frons vertical, with only a short median stria, many piliferous punctures, the fine structure matt; vertex angled to frons, the V-impression conspicuous. Pronotum longer than wide $(15: 12)$, median stria well developed, no pronotal pores, surface shining. Elytra a little wider than pronotum and more than twice as long, lateral margins barbed, ending in strongly angled near vertical declivity; interstriae and striae only clearly evident in last fifth of disc, where first six interstriae reach and project individually over declivity ; declivity shallowly rimmed, with very short projections at apex, evidence of the first six interstriae appears at the top of the declivity. surface with many coarse granules, matt, piliferous. Abdominal ventrites punctured, shining.

Female 3.5 to $3.6 \mathrm{~mm}$ long, and nearly four times as $\log$ as wide. Colour, head and pronotum brown, elytra yellow. Head and Pronotum like male except for larger pore-groups, the pores circular. Elytra without strongly angled declivity, instead this is initially convex, with the sulcus impressed, and then vertical, the latter bordered above by oblique ridges, and covered with piliferous granules.

Holotype $\sigma^{\top}$, Papua New Guinea : Gumi, Watut Logging Area, Bulolo, 2,200 m, ex Syzigium sp., 1. v. 86 (H. Roberts) (BMNH). Paratypes $20^{\top} 2$, same data as holotype, $10^{\top} 1 q(\mathrm{BMNH}), 10^{\top} q$ (FRS, Bulolo).

P. lingulatus is close to $P$. tmncaticauda Schedl of the Group 'Platypi truncatipenni'. Males of this new species are separated by their larger size, and in that they have the first six interstriae projecting over the declivity, not three, while the elytral apices are much less produced.

\section{Platypus margari taceus sp. nov.}

Male 3.0 to $3.1 \mathrm{~mm}$ long, and more than four times as long as wide. Colour brown, the head and elytral apices black. Head frons lightly impressed, median stria short, surface finely reticulate, with few hairs. Pronotum longer than wide (24:21), femoral grooves strongly angled posteriorly, median stria surrounded by elongate pore-groups, surface shining, few punctures. Elytra nearly twice as long as pronotum, sides almost parallel, ending in strongly convex declivity, which occupies the final third ; disc dull, interstriae and striae evident up to commencement of declivity, except interstriae 1 , which is very narrow, the remainder subequal, striae hardly impressed, except the first ; declivity at first 
horizontal, then near vertical, both interstriae and striae recognizable up to change in slope, with the former distinguished by polished granules on a matt surface, particularly on 1 and 3, subsequently interstriae continued onto declivity as rows of granules, the terminal granule of row 5 on the elytral margin larger, all granules bearing stiff horizontal hairs. Abdominal ventrites matt, impunctate, with many hairs.

Holotype ơ, Papua New Guinea ; Kaisenik, Wau, 2,000 m, ex Nothofagus sp., 22. ii. 76 (H.

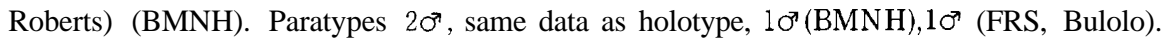

This species is in the Group 'Platypi sulcati' (Chapuis 1965), perhaps near P.vetulus Schedl. The ornamentation of the declivity summit will distinguish this from other members.

\section{Platypus parapetax sp. nov.}

Male 2.3 to $2.4 \mathrm{~mm}$ long, and four times as long as wide. Colour head, thorax and elytral apices dark brown, remainder of elytra yellow. Head frons impressed centrally, short median stria distinct, surface finely reticulate, with scattered piliferous punctures ; vertex not strongly angled to frons, median stria not prominent. Pronotum clearly longer than wide (28:19), femoral grooves not strongly angled, median stria very short, impressed, no pronotal pores evident, surface finely reticulate, dull, with many small punctures. Elytra narrowest just before declivity, nearly twice as long as pronotum, ending in narrow toothed declivity ; disc shining, all interstriae evident, but none extending onto declivity, striae seriate punctate, only first impressed ; declivity narrow, no evident teeth on upper margin, but posterior margin showing three teeth on each elytron, those opposite interstriae 3 and 7 short, that opposite interstriae 5 much larger, and pointing nearly vertically downwards, surface transversely carinate above, smooth behind. Abdominal ventrites shining, the last punctate, and virtually free of hairs.

Holotype ơ, Papua New Guinea :Gumi, Watut Logging Area, Bulolo, 2,200 m, ex Dysoxylum sp., 21. xii, 85 (H. Roberts) (BMNH). Paratype 10', same data as holotype (FRS, Bulolo).

This small platypodid belongs properly in the 'Platypi semidepressi' (Schedl 1939). It resembles $P$. petax Schedl from which the males can be separated by the much shorter pronotal stria with no pores, and by the absence of any teeth on the upper margin of the declivity.

\section{Platypus partibilis sp. nov.}

Male 3.2 mm long, and four times as long as wide. Colour head and elytra dark brown, pronotum paler. Head frons somewhat impressed, median stria strong, surface matt, with fine elongate punctures ; vertex not angled to frons, median stria short. Pronotum longer than wide (18:15), femoral grooves shallow, angled posteriorly, median stria completely surrounded+ by elongate poregroups, surface shining, with scatterred fine punctures. Elytra little wider than pronotum, but two and a half times as long, widest halfway, then narrowing to declivity with a pair of forceps-like projections which occupy the posterior third ; disc shining, interstriae all subequal in width and about the same length, and all reaching the beginning of the declivity, striae seriate punctate, not impressed ; declivity convex and narrowing, interstriae 3 to 5 extended on each elytron as an elongate projection that is turned slightly inward, with at its base one distinct granule, interstriae continued onto declivity as rows of hairs, surface throughout matt. Abdominal ventrites matt, with few rows of long hairs.

Holotype ơ', Papua New Guinea :Gumi, Watut Logging Area, Bulolo, 2,200 m, ex Syzigium sp., 13. ii. 86, (H. Roberts) (BMNH).

This platypodid belongs to the 'Platypi oxyuri' and is close to $P$. giluwei Roberts. The male of P. partibilis can be separated by its smaller size, and the form of the declivity, where the surface is 
more matt, the hairs more bristly, and the projections stronger.

Platypus petalinus sp. nov. (Fig. 24)

Male $3.3 \mathrm{~mm}$ long, and a little more than four times as long as wide. Colour head and elytra brown, the thorax orange. Head lightly impressed centrally, median stria short, surface finely reticulate, with few hairs ; vertex not strongly angled to frons. Pronotum longer than wide (27:25), femoral grooves angled behind, median stria completely surrounded by pronotal pore-groups of elongate pores, surface shining, punctate, most densely in front of pore-groups. Elytra more than twice as long as pronotum, widest at summit of inclined declivity ; disc dull, finely reticulate all over, interstriae and striae distinct throughout elytra, interstria 2,3,4, and 6 ending as spines over the declivity, 8 ending bluntly, while 9 continues further than the remainder, striae seriate punctate, but only impressed apically; declivity at first inclined then near vertical, the inclined area covered with granules together with dense rows of long hairs which represent the interstriae, the vertical area glabrous, shining, impunctate, bordered by two pairs of teeth, the upper pair hooked, the lower simple and narrow. Abdominal ventrites shining, punctate, the fourth with a pair of blunt teeth.

Female $3.8 \mathrm{~mm}$ long, and more than four times as long as wide. Colour as male, but more yellow. Head frons not flat, median stria situated on a raised area, surface coarsely punctate about the stria, above this much more finely punctured and few hairs ; vertex not angled to frons. Pronotum similar to male except median stria longer and surrounded by much larger pore-groups. Elytra of similar width to pronotum, but nearly three times as long, sides near parallel, declivity occupying final fifth ; interstriae and striae visible throughout disc of elytra, stria seriate punctate ; declivity transversely carinate at first, then vertical, the suture here impressed, and with few hairs, on the vertical surface densely haired, except for a glabrous sutural strip.

Holotype ${ }^{\natural}$, Papua New Guinea : Gumi, Watut Logging Area, Bulolo, 2,200 m, ex Nothofagus sp., 6. iv. 76 (H. Roberts) (BMNH). Paratype 19, same data as holotype (BMNH).

P.petalinus is similar to P.petaloideus Roberts (Fig. 25), known from Mt. Giluwe, and there also from No thofagus. Both species probably should be placed in the Group 'Platypi quadrifissi' (Chapuis 1865). Males of this new species can be separated particularly by the declivity ornamentation, where there are only two conspicuous pairs of teeth in P.petalinus, and these are smaller.

Platypus pulvinatus sp. nov. (Fig. 26)

Male 2.8 to $2.9 \mathrm{~mm}$ long, and four times as long as wide. Colour orange brown, the elytral apices black. Head frons near vertical, median stria prominent, long, surface finely reticulate, with scattered piliferous punctures ; vertex strongly angled to frons, median stria prominent. Pronotum longer than wide $(30: 26)$, femoral grooves angled posteriorly, median stria strong, with two sizeable poregroups occupying the anterior half, the individual pores elongate, surface shining with few punctures. Elytra some two and a half times as long as pronotum, widest at summit of declivity, the latter occupying the distal quarter of the elytra and distinguished by numerous spines and hairs projecting posteriorly ; disc shining, interstriae clearly evident in the distal half only, where all reach the declivity summit, but only $3,5,8$, and 9 project over it, the first two as hooked horizontal teeth, the others as blunt teeth, 8 subapically separated, and 9 , the most prominent of all pointing obliquely downwards, striae all seriate punctate, impressed only near the declivity summit ; declivity swollen, gradually inclined posteriorly, the apex somewhat indented, surface matt, ornamentation granular, with one granule stronger opposite interstria 3 on each elytron, hairs conspicuous in the upper half only. Abdominal ventrites shining, punctured, the last but one with two short blunt processes, 

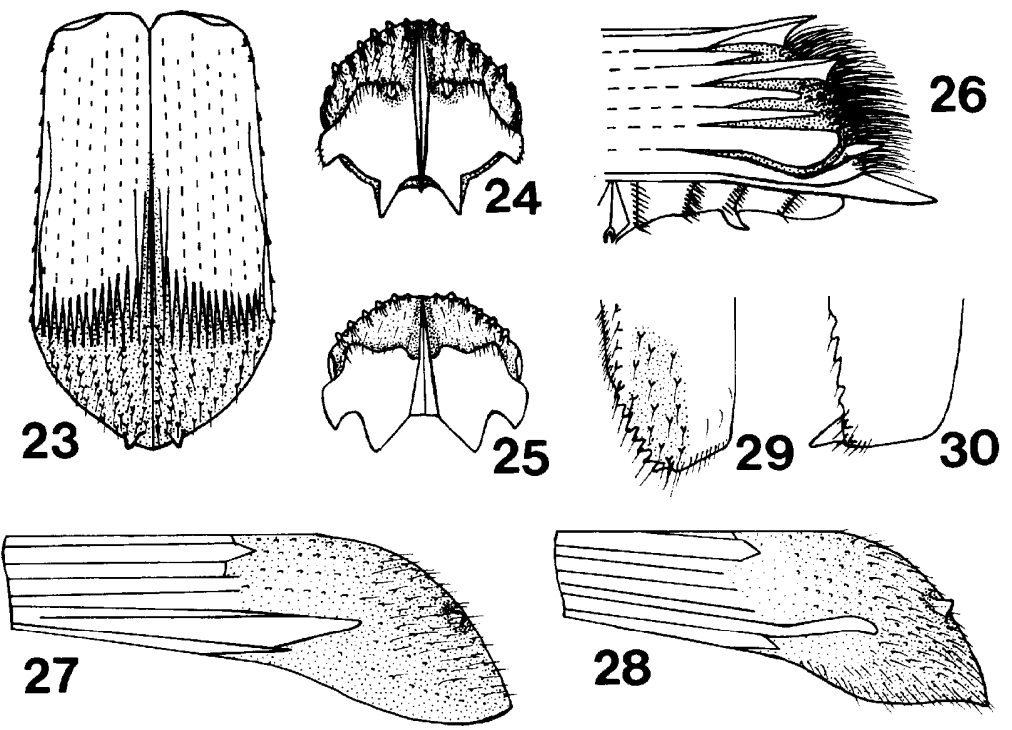

Figs. 23-30. Platypus bipyramidus sp. nov. : 23. dorsal view male elytra. P. petalinus sp. nov. : 24 . posterior view male declivity. P. petaloideus Roberts (for comparison) : 25. posterior view male declivity. $P$. pulvinatus sp. nov. : 26. lateral view apex male elytron. P. ambiguus sp. nov. : 27. lateral view male elytron. P. uniformis Schedl (for comparison) : 28. lateral view male elytron. Baiocis nubilosus sp. nov. : 29. lateral view apex male elytron. B. unispineus Roberts (for comparison) : 30 . lateral view apex male elytron.

numerous hairs.

Female 3.1 to $3.2 \mathrm{~mm}$ long, and nearly five times as long as wide. Colour yellow brown. Head and Pronotum resembling the male, except that the pronotal pore-groups are much larger, each occupying the full length of the median stria, and individual pores are elongate. Elytra elongate, near parallel sided, the declivity occupying the distal fifth, suture impressed along its complete length, particularly at declivity summit ; all interstriae and striae evident throughout, though none prominent, and seriate punctate, striae not impressed ; declivity at first inclined then near vertical, this change in slope marked by oblique ridges which on the margins form short teeth, the final vertical part some what impressed, and densely covered with hairs, except along the suture. Abdominal ventrites without any projections.

Holotype ơ, Papua New Guinea ; Gumi, Watut Logging Area, Bulolo 2,200 m, ex unknown host,. 18. v. 77 (H. Roberts) (BMNH). Paratypes $10^{\top} 2$ 으, same data as holotype, $10^{\top}(\mathrm{BMNH}), 10^{\top} 1 \%$ (FRS, Bulolo).

P. pulvinatus belongs to the Group 'Platypi quadrifissi' (Chapuis 1865). Males by their larger size are separated from $P$. evanidus Roberts, and by the ornamentation of the elytra from P.opimus Schedl and P.circulariceps Schedl, the new species not having the first two pairs of interstriae prominent as in both these species.

Platypus ramosissimus sp. nov. (Figs. 12, 13)

Male 3.6 to $3.7 \mathrm{~mm}$ long, and nearly five times as long as wide. Colour black. Head frons flat, no median stria but a small definite central area impunctate, surface with elongate punctures, with 
some hairs; vertex angled to frons, surface covered densely with elongate punctures. Pronotum longer than wide $(39: 28)$, femoral grooves angled posteriorly, stria distinct, with clear well spaced pore-groups in anterior half, surface with scattered fine punctures. Elytra hardly wider than pronotum, but more than twice as long $(43: 19)$, sides initially bulbous but contracting half way down declivity, to again expand as many branches around the declivity rim ; disc shining, interstriae 1 narrow, the remainder subequal, 1 and 2 stopping at the start of the declivity, the others, except 9 , fused together as a 3-pronged branch which projects over each half of the declivity, the striae, except the first which is impressed along all of its length, impressed only apically; declivity gradually inclined, occupying the posterior third of the elytra, its margin raised on each elytron, dorsally as a short tooth, and below that as two more elongate, narrower teeth, the lower tooth ultimately bifurcate, surface smooth and shining with very few hairs. Abdominal ventrites smooth, with numerous strong hairs.

Female 3.4 to $3.5 \mathrm{~mm}$ long. Colour black. Head and Pronotum essentially like the male except that the frons has a distinct median stria, and the pronotal pore-group is much larger, occupying more than half the median stria. Elytra more than twice as long as the pronotum, with declivity restricted to apical quarter ; disc shining, only interstriae 1 distinct, remainder evident only at base of elytra and commencement of declivity, likewise the first stria is the only one evident for its complete length ; declivity at first gradually inclined, and then near vertical, the latter part with two short blunt teeth marginally on each elytron, surface at first transversely carinate, and then granular, with a dense cover of short hairs.

Holotype ơ, Papua New Guinea :Gumi, Watut Logging Area, Bulolo, 2,200 m, ex dying Cryptocaria sp., 20. ii. 86 (H. Roberts) (BMNH). Paratype 19, same data as holotype (BMNH).

This platypodid, belonging to the 'Platypi adjuncti' (Schedl 1939) was taken in a wild tree dying with heart-rot. Males of P.ramosissimus are easily distinguished by the much branched declivity.

\section{Platypus ramulosus sp. nov. (Figs. 1, 2)}

Male $6.4 \mathrm{~mm}$ long. Colour black. Head frons flat, with no central stria, surface with elongate pores containing hairs, fine structure reticulate ; vertex not strongly angled to frons, with similar type punctures. Pronotum longer than wide $(55: 40)$, femoral grooves shallow, median sulcus clear, with no evident pore-group, surface shining with many fine pits. Elytra hardly wider than pronotum, but twice as long, sides near parallel, ending in inclined declivity surrounded by three pairs of large subequal teeth; disc shining, interstriae smooth, 1 much narrower than the remainder ending in a short tooth over the declivity, 2, 5, 6, and 7 likewise, while the others form large teeth over the declivity, 3 and 4 fused together, 8 and 9 separately, the latter downwardly pointing, all striae seriate punctate, the first alone impressed along its complete length ; declivity inclined with three pairs of large teeth surrounding it, the first and third on each elytron having single small teeth hidden beneath each, surface entirely smooth, with single hairs between and below the large teeth. Abdominal ventrites shining, punctured, with scattered hairs.

Holotype ơ , Papua New Guinea : Gumi, Watut Logging Area, Bulolo, 2,200 m, ex Cryptocaria sp., 23. xii. 76, (H. Roberts) (BMNH). Paratype 10 , same data as holotype (FRS, Bulolo).

$\boldsymbol{P}$. ramulosus closely resembles $\boldsymbol{P}$. runcinatus Roberts, and like it belongs to the 'Platypi adjuncti'. Males of the new species can be distinguished by their much larger size, and by the much larger posterior pair of pointed teeth on the declivity. 


\section{Platypus refractus sp. nov.}

Male $2.6 \mathrm{~mm}$ long, and more than four times as long as wide. Colour yellow brown except for black elytral apices. Head near flat, median stria short, surface finely reticulate, few hairs; vertex not strongly angled to frons. Pronotum almost square, anterior and posterior femoral angles similar, median stria short, with numerous elongate pores making up the two pore-groups, each of which occupies the whole length of the median stria, surface shining with many variably sized punctures. Elytra widest at summit of declivity, which occupies the distal fifth, and is at first inclined and then near vertical ; disc shining, interstriae 1,3, 5, 6 and 7 conspicuous distally as horizontal spines, 8 and 9 also, but blunt, and the latter inclined downwards, striae distinct only distally, seriate punctate basally ; declivity surrounded by seven pairs of projecting teeth, surface matt, with many granules. Abdominal ventrite matt, the fifth covered with punctures, and the fourth bearing a pair of prominent knobs.

Holotype ơ , Papua New Guinea : Gumi, Watut Logging Area, Bulolo, 2,200 m, ex unknown host, 18. v. 77 (H. Roberts) (BMNH).

This platypodid, a member of the 'Platypi quadrifissi', is very similar to $P$. circulariceps Schedl. Besides its larger size $P$. refractus can be distinguished by the larger pore-groups on the pronotum, and the steeper, more convex declivity.

Platypus sellaeformis sp. nov. (Figs. 9,10,11)

Male 3.3 to $3.4 \mathrm{~mm}$ long, and five times as long as wide. Colour black. Head frons slightly convex, between the eyes a short median stria, surface finely ruminate, few hairs ; vertex not strongly angled to frons. Pronotum clearly longer than wide (29:21), femoral grooves angled posteriorly, median stria distinct, surrounded by large, near cordate, pore-groups, surface coarsely punctured with variable sized pores. Elytra not wider than pronotum, but two and a half times as long, near parallel sided, with a large strongly carinate projection terminating each elytron apically; disc shining, all interstriae clearly recognizable, 3 more prominent than the remainder, striae also distinct throughout, all seriate punctate ; declivity matt, each elytron with extension of interstriae 3 making the axis of a carinate projection, and 7 the axis of a lateral flange, most striae clear as thin black shiny lines, surface without punctures, but each interstriae marked with a row of small hairs, Abdominal ventrites shining, punctate.

Female 3.2 to $3.3 \mathrm{~mm}$ long. Colour black. Head and Pronotum very like the male except the pronotal pore-group larger, and slightly raised, and the surface more densely punctured. Elytra the same width as the pronotum, and more than twice as long, in form somewhat bulbous with declivity at first gently convex, before ending vertically ; interstriae all clear for whole length of disc, shining, 3 slightly more prominent than the remainder, striae impressed, seriate punctate ; declivity on vertical face laterally notched, followed by a short projection on each elytron, with the elytral sulcus indented posteriorly, surface raised where elytra meet, otherwise on vertical face granulose, with many short hairs.

Holotype ơ', Papua New Guinea :Gumi, Watut Logging Area, Bulolo, 2,200 m, ex dying Cryptocaria sp., 20. ii. 86 (H. Roberts) (BMNH). Paratypes $10^{7} 2$, same data as holotype, 19 (BMNH), $10^{\top} 1$ (FRS, Bulolo).

P.sellaeformis belongs to the 'Platypi adjuncti'. Males are easily recognizable by the projections of the declivity, females by the ornamentation of the pronotum and declivity. This species is amongst the last to emerge from fallen logs attacked at high altitude, and like $P$. ramosissimus it attacks sickly trees. 

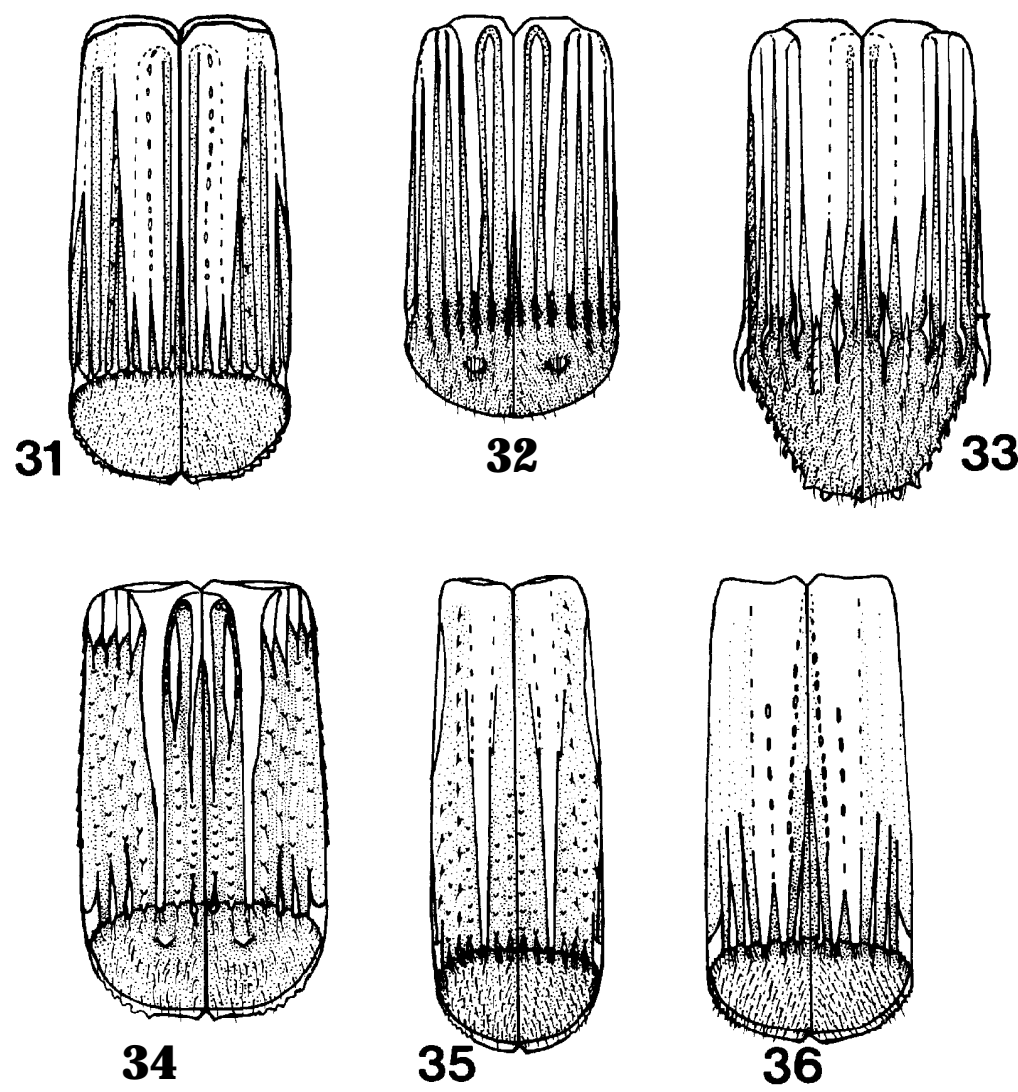

Figs. 31-36. Dorsal views male elytra :31. Platypus torulosus sp. nov. ;32. P. evanidinervius sp. nov. ; 33. P. echinatus sp. nov. ; 34. P. aspicis sp. nov. ; 35. P. glochideus sp. nov. ; 36. P.lingulatus sp. nov.

Platypus torulosus sp. nov. (Fig. 31)

Male 4.4 to $4.5 \mathrm{~mm}$ long, and some three and a half times as long as wide. Colour reddish black. Head frons near flat, a short median stria evident, surface matt, finely reticulate, with numerous piliferous punctures; vertex strongly angled to frons, central V-impression unusually narrow. Pronotum longer than wide (40:33), median stria distinct, no pore-groups evident, surface shining, with scattered punctures, Elytra nearly twice as long as pronotum, sides diverging only slightly, ending in steep, near vertical declivity ; disc shining, intertstriae 1 alone complete throughout, the remainder fused to different degrees, in particular 2 and 3 until the final quarter, only the first three interstriae reaching the declivity separately, the remainder fused, and no interstriae obviously projecting over the declivity anywhere, striae initially all seriate punctate, but distally all are partly impressed ; declivity near vertical, with no sign of interstriae, surface matt, covered with small flat granules of different sizes, no rim evident, margin and general surface with only short inconspicuous hairs. Abdominal ventrites shining, the last well punctured, few hairs.

Female 4.7 to $4.8 \mathrm{~mm}$ long, slimmer in appearance than the male. Colour dark red. Head and Pronotum as the male except that the latter has two large pore-groups occupying the full length of the median stria on either side, cordate in shape. Elytra simpler than the male, with declivity 
occupying all the final quarter ; all interstriae and striae evident throughout their length, the latter seriate punctate, none extend onto declivity ; declivity at first convex, then vertical, the former part, which has only few hairs, separated from the latter by oblique ridges that do no meet in the centre, vertical part with much denser covering of hairs, the central strip glabrous.

Holotype ơ , Papua New Guinea : Latep, Watut Logging Area, Bulolo, 2,000 m, ex unknown host, 20. vii. 76 (H. Roberts) (BMNH). Paratypes $10^{\top} 2$, same data as holotype, 1 ( $\left.\mathrm{BMNH}\right), 10^{\top} 1 \%$ (FRS, Bulolo).

P.tomulosus resembles P. turriformis sp. nov., both belonging to the Group 'Platypi sulcatotruncati'. The fusion of interstriae 2 and 3 of the elytra up to the distal quarter, the absence of any conspicuous tufts of hairs over the declivity, and of recognizable interstriae on any part of this declivity, separate the males of P.torulosus; the very large pronotal pore-groups distinguish the females.

Platypus turriformis sp. nov. (Figs. 19, 20, 21)

Male 4.4 to $4.5 \mathrm{~mm}$ long, and three times as long as wide. Colour brown, the elytral apices black. Head frons near flat, the median stria very short, surface finely reticulate, with piliferous punctures ; vertex angled to frons, with well developed inverted V-impression, margined with hairs. Pronotum longer than wide $(25: 21)$, the posterior median stria distinct with no pore-groups, surface shining, with punctures mainly at the anterior and posterior limits. Elytra less than twice as long as the pronotum (40:25), and not wider, ending in a sharp, truncate declivity; disc shining, interstriae 1 the narrowest, and alone distinct throughout its entire length, 2, 3, and 4, and 8 and 9 basally joined, the first three for most of the disc, interstriae 5, 6 and 7 incomplete, striae partially or completely impressed, generally impunctate ; declivity abrupt, the first five interstriae carried over onto the top of the declivity, where each bears a thick brush of short hairs, margin of the declivity raised, surface covered with many ovoid granules, all of them small. Abdominal ventrites shining, with many punctures, but very few hairs.

Female 4.6-4.7 mm long. Colour paler, more uniform brown than the male. Head and Pronotum similar to the male except the median stria of the frons more prominent, and two pore-groups present on the pronotum, one on either side of the median stria. Elytra more elongate than the male, and simpler, all interstriae distinct, each separated by punctate striae, none of which are strongly impressed ; declivity confined to the apical quarter, at first gently inclined then vertical the change in slope marked by an oblique ridge on each elytron, surface of the vertical part granulous, and covered with short hairs.

Holotype ơ, Papua New Guinea : Upper Stony Logging Area, Bulolo, 1,600 m, ex Xanthophyllum papuanum, 28. viii. 86, (H. Roberts) (BMNH). Paratypes 10'19, same data as holotype, 1 (으 (BMNH), $10^{\top}$ (FRS, Bulolo).

This species in the Group 'Platypi sulcato-truncati' has similarities to P.truncatigranosus Schedl. P. turriformis males are distinguished by their larger size, by the shorter lengths of interstriae 2 and 3 that remain separated, and by the absence of any prominent bosses on the declivity.

\section{Acknowledgements}

Gratitude is acknowledged to all colleagues of the senior author at the Forest Research Station, Bulolo, in particular to Messers H. Ivagai and J. Dobunaba, the latter who was responsible for all the illustrations in this article. This paper is published with the permission of the Secretary, Department of Forests, Port Moresby. 


\section{References}

Chapuis, F. 1865. Monogr. Platyp.: 233-252. Liege.

Gray, B. \& Wylie, R. 1974. Pacific Insects, 16(1): 67-115.

Johns, R. J. 1982. Plant Zonation in Papua New Guinea, in 'The biogeography and ecology of New Guinea'. Edit. J. L. Gressitt : 309-330. Junk, The Hague.

Roberts, H. 1979. Jnl. nat. I-list., 13 : 81-98. -1986. Esakia, (24) : 37-58.

Schedl, K. E. 1939. Int. Kongr. Ent., 7 : 398. -1970. Proc. Linn. Soc. NSW., 94(3) : 214-236. -1972a. Monogr. der Familie Platypodidae. 332 pp. Junk, den Haag. -1972b. Papua New Guinea Agric. J., 23(3) : 49-72. -1975. Ann. Naturhist. Mus., 79 : 23-399. 